In the course of his speech, Prof. Boys said :

"We have met to-day to express our appreciation of the valuable services which have been rendered by $\mathrm{Mr}$. Colebrook during the last forty years. During this time he has made us all his debtors on account of his industry, his good temper, his willingness and desire to help, and, above all, by his consummate skill as a craftsman.

"When I see now the magnificent collection of tools which in the present century has grown up under his guidance, and contrast it with the meagre equipment of my time, I feel that the early history of the workshop-which no one else but myself can give-and of the introduction of $\mathrm{Mr}$. Colebrook is of sufficient general interest for me to recount.

"About the year 1873, Prof. Guthrie made out an order for a small general purpose lathe, but this order was stopped when it got to the museum, and the official answer, put colloquially, was - 'Lathe? What can you possibly want with a lathe in a physical laboratory? If you have anything which you want to be turned, let us have it and we will get it turned in the museum workshop.' Well, Prof. Guthrie was Scotch and very persistent, and General Festing, R.E., the engineer in charge of the museum and workshops, was a delightful, genial, and jovial friend of all who came his way. The result was, skipping intermediate steps, that a little 4 -inch Cotton and Johnson lathe was acquired, and, though a poor little thing, it was in constant use and proved itself invaluable.

"Coming now to the second chapter, about the year 1890, Prof. Rücker and I felt that we must have something better, and it was left to me to select a suitable lathe, but with the strictest attention to cost. There was very little money, and we did not want to draw a second refusal similar to the first. I selected what I considered the best possible lathe for physical laboratory requirements that was not too expensive. This was the Barnes $5 \frac{1}{2}$-inch centre lathe, and after forty years I still consider that I could not have done better. I got the identical lathe for myself a few years later, and this is all I have for my own use to the present day. It may be interesting to state that when Prof. Mendenhall came to see me, he said - "Why, that is the lathe on which Rowland cut his famous serew - the screw of his diffraction grating machine'.

"Having now a suitable lathe, it was essential that there should be a skilled mechanic to use it and to protect it from misuse, and again $I$ was asked to find him. I heard of Mr. Colebrook, and got him to come for a preliminary discussion. I asked him to do something with the new lathe and with a file, and, being a bit of a mechanic myself, I saw with half an eye that his handling of these tools showed him to be a skilled craftsman.

"This was the time when I was preparing my apparatus for weighing the earth, which I did at Oxford. 'The main apparatus was made by the Cambridge Scientific Instrument Co., but much had to be done besides, and this construction was done partly by Colebrook (I must now drop the Mr.) and partly by myself. It was then that I learned to appreciate not only Colebrook's skill but also his conscientious devotion to the work. About the same time I was photographing bullets, and I required a very perfect revolving mirror to analyse the sparks that I used in order to get one bright enough, small enough, and of short enough duration so that the bullet should not travel more than $\frac{1}{50}$ inch while it was being photographed. I designed this to be made in dead-hard tool steel. Colebrook made it to perfection, and it was figured by Hilger. We ran this at 500 revolutions per second for ordinary use, but we did run it up to 1500 revolutions per second, at which it ran well. This is nearly twice the speed at which Foucault ran his mirror when determining the velocity of light, and my mirror would have shown the time taken by light to traverse the length of this lecture table. It was to Colebrook that I owed the success of this mirror."

\title{
A New Method of Measuring High Frequency Voltages.
}

$\mathrm{I}^{\mathrm{N}}$ the Elektrotechnische Zeitschrift for Aug. 13, L. Pungs and H. Vogler describe a new electrooptical method of measuring voltages of very high frequencies. In practice, some type of electrometer is generally employed, but with very high frequencies its readings are untrustworthy. The authors made a test on a good electrometer of a type usually employed, and found that up to one and a half million cycles per second it gave accurate and consistent results, but at twelve million cycles its readings were ineorrect by errors lying between thirty and forty per cent. As these instruments are largely used in radio work for making investigations on the dielectric behaviour of insulating materials, it was necessary to find the cause of the inaccuracies and either correct their design or try to invent a new method. The errors of the instrument were found to be mainly due to the fact that its capacitance varied with its deflexion, for this led to resonance effects which made the readings quite irregular.

The authors have found a practical solution applicable to many cases. They utilise the well-known Kerr effect in electro-optics, which has been studied carefully by many physicists. The physical basis of their method is to use a monochromatic source of light, a Nicol's prism as polariser, a cell containing nitrobenzene subjected to electric stress between two parallel metal plates, maintained at the voltage to be measured, and a second Nicol's prism as analyser. The field of view is first extinguished by crossing the prisms when the voltage is not applied. On applying the voltage, light comes through owing to the Kerr effect. If the voltage be alternating, the intensity of the light is a periodic function of the time.

The authors obtain a mathematical formula for the mean intensity of the light passing through, showing that, on the supposition that there is no inertia effect, it is independent of the frequency of the alternating voltage. Making sine wave assumptions also, they prove that it is proportional to the maximum value of the electrostatic field. With the help of tables of Bessel's functions they calculate the maximum voltage, which can be found in terms of the mean light intensity. Since the mean light intensity is independent of the frequency, the instrument can be calibrated with low frequency voltage.

The main difficulties that had to be overcome in comnexion with the method are, first, that the Kerr constant varies very appreciably with temperature. Hence unless the temperature remains constant it has to be measured and a correction applied. The calibration also depends on the intensity of the source of light; it is therefore necessary to specify accurately the source of the light. The calibration is only accurate for light of a definite wave-length. The authors, therefore, were led to develop a comparison method which enables a higher accuracy to be obtained.

In this method the Kerr arrangement is adjusted so that the field is dark with zero voltage, a photoelectric cell being employed. The voltage is then applied to the Kerr cell, and the illumination of a second photoelectric cell is adjusted to a balance by

No. 3247, VoL. 129] 
means of an electric circuit. The high frequency voltage is then cut out and a fifty cycle voltage applied, and the electric circuit is adjusted until the balance is the same as before. In this way the effective value of the high frequeney voltage can be found. The comparisons are made rapidly, so that the temperature of the Kerr cell remains practically constant; and the necessity of applying a temperature correction is eliminated. So long as the colour of the light is the same when making the two comparisons, it is not necessary to know its wave-length.

According to results obtained by physicists, it can be assumed that up to frequencies of thirty million cycles per second the Kerr effect is free from inertia.
In this case the wave-length is ten metres. The authors suggest that it can probably be used down to five metre wave-lengths. They have used the method for voltages lying between 300 and 4000 volts. The highest frequency they used was twelve million cycles (25 metres). By using a Pulfrich photometer and applying a direct method they found that the error was 1 per cent when the applied voltage was 800 and 0.33 per cent at 1800 volts. With the photoelectric method the error was 2 per cent at 800 volts and $0 \cdot 1$ per cent at 1800 volts. This method has the disadvantage that the photoelectric cells and the amplifying apparatus have to be carefully screened.

\section{Annual Conference of the Geographical Association.}

THE Annual Conference of the Geographical 1 Association was held at the London School of Economics, by kind permission of the director, Sir William Beveridge, on Jan. 6-8. As usual, the Conference was well attended by delegates and members from all parts of Great Britain, and at some of the lectures the audience exceeded four hundred. A representative publishers' exhibition, in which twentysix firms took part, was held in conjunction with the Conference. At the termination of the proceedings in London, according to established custom, a party of mernbers spent the week-end in a country town, this year at Rochester.

of outstanding importance was the presidential address by Sir Leslie Mackenzie, entitled" A Health Administrator's Attitude to Geography ". The work of the medical profession deals increasingly with the prevention of disease as opposed to the cure of disease, and for the medical officer of health geography must be his guide ; for geography is the study of the earth as the environment of man, and Sir Leslie referred to the "flowingly intimate" correlation between health conditions and geography. In Scotland the three million population of the Midland Valley contrasts with the 420,000 people of the Highlands-a reflection of relatively favourable and relatively unfavourable geographical conditions. A study of malnutrition amongst Highland schoolchildren has shown an intimate connexion with bad harvests, which in turn reflect fluctuations in climatic conditions from vear to year in a region where other geographical factors such as physiography and soil exercise a somewhat rigid control.

Coming to details, Sir Leslie pointed out that geographers have long emphasised the importance of aspect in influencing the distribution of natural vegetation and crops. It is equally important in determining health conditions. There are valley sides "half starved of sun for a million years " which must inevitably remain disease traps for their human in habitants when compared with the opposite slopes of the same valleys. Further reference was made to the geographical methods of mapping distributions and of determining limiting factors in each case. There is need for the health administrator to follow these methods. What, for example, is the limit of distribution of tetanus in the soil of France? Is it coextensive with a certain type or certain types of soil? The widespread distribution of tetanus in Flanders soil was one of the great problems which had to be tackled by the medical service during the War. Modern developments, for example, in the field of transport must not be ignored by the medical officer; it has been shown, for example, that diseasebearing mosquitoes can be carried 12,000 miles by aeroplane. In short, the work of the health officer provides a new motif for the study of geography and the employ of cartographical methods of studying distributions.

The work of the Conference included aiso an important joint discussion with the Historical Association on "What is Historical Geography?" Prof. C. B. Fawcett undoubtedly stated the main difficulty when he said that there are so few equipped with an adequate training in both geography and history, and that until students so equipped are forthcoming the present confusion is likely to continue. He referred to Sir Halford Mackinder as a historian who has become a great geographer, and has expressed the relationship between the two sciences by saying that every event occurs both in space and time and is thus the concern both of geographer and histopian, though, of course, not all events are of equal importance to either student.

The discussion made it clear that many of the historians present were inclined to equate ' geography' to 'physical geography' and failed to appreciate the modern human geography. Thus, Dr. J. E. Morris stated: "A geographer can only introduce the subject, for, when he has told us all about climate and situation, environment and stimulus, geological conditions and rainfall, it remains for the historian to show how men have used their opportunities". There was clearly no appreciation of geographical synthesis, of the study of the environment as a living concrete whole, continually acting and reacting on the central figure of man. Similarly, Prof. F. S. Marvin referred to the natural factors, "the river, the mountain, or the sea ", and was obviously limiting his conception to the factors of physical geography. On the other hand, Prof. A. P. Newton showed elearly that he represents a school of his. torians having a clear conception of the methods and value of modern geography. Prof. E. G. R. Taylor showed how a descriptive topographical introduction accompanying historical works has come to receive the label 'historical geography' for what should be merely the geography of history. Indeed, the whole discussion made it clear that both geographers and historians have been guilty of selfishness : geographers using some of the results of historians to further geographical knowledge, historians using fragments of geography here and there for the advancement of historical studies. A plea was made whereby the Geographical and Historical Associations might devise some scheme for the exchange of research data. Miss Jeffries Davis, editor of History, surprised many of her listeners by finding a common requirement of both historians and geographers outside the direct sphere of either-the early completion of the "drift' edition of the geological maps of Britain.

Dr. Gerhard Schott, the well-known oceanographer

No. 3247, Vol. 129] 